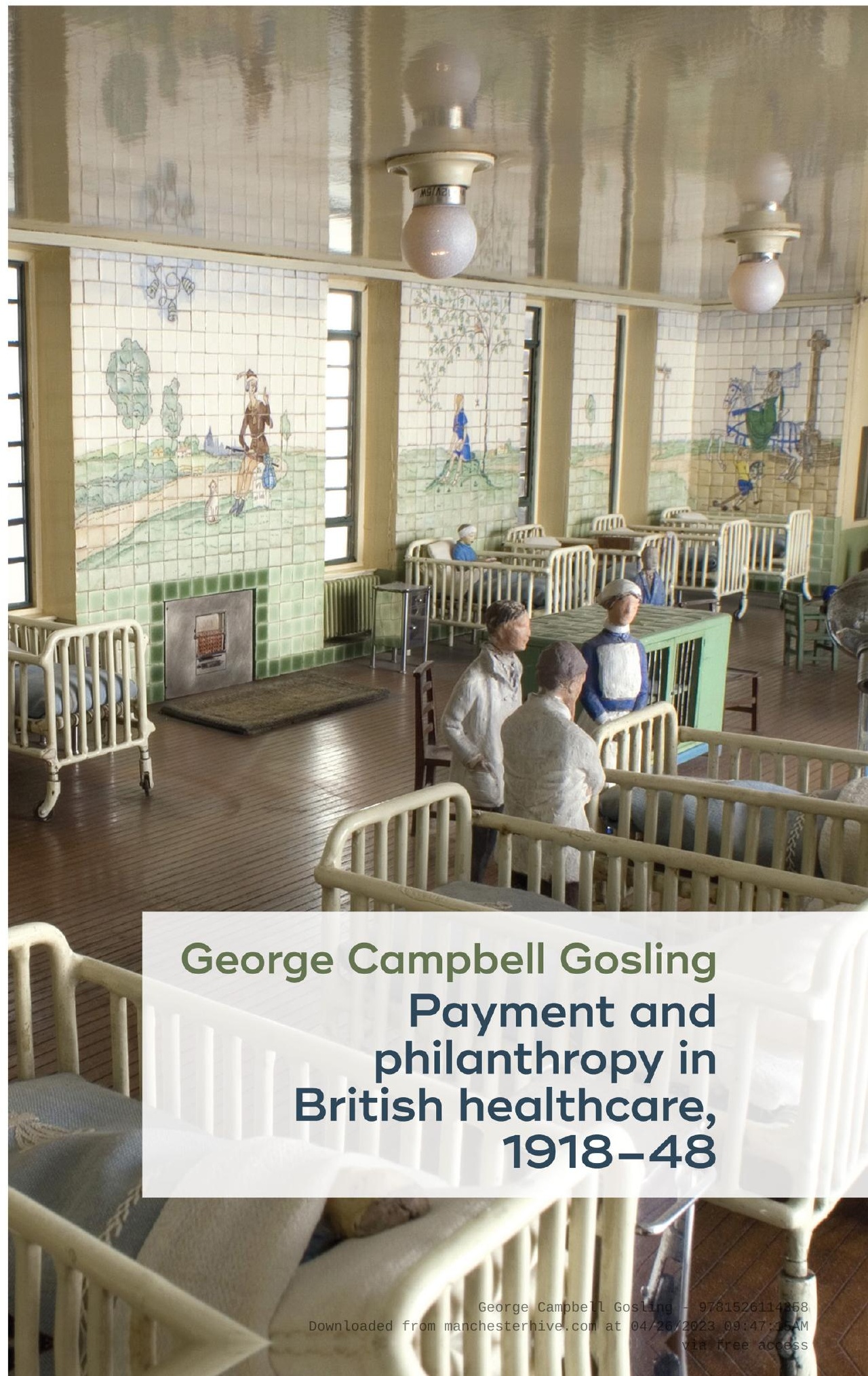




\section{Payment and philanthropy in British healthcare, 1918-48}

\section{MANCHESTER \\ 1824}

Manchester University Press 


\section{SSH}

\section{SOCIAL HISTORIES OF MEDICINE}

Series editors: David Cantor and Keir Waddington

Social Histories of Medicine is concerned with all aspects of health, illness and medicine, from prehistory to the present, in every part of the world. The series covers the circumstances that promote health or illness, the ways in which people experience and explain such conditions, and what, practically, they do about them. Practitioners of all approaches to health and healing come within its scope, as do their ideas, beliefs and practices, and the social, economic and cultural contexts in which they operate. Methodologically, the series welcomes relevant studies in social, economic, cultural and intellectual history, as well as approaches derived from other disciplines in the arts, sciences, social sciences and humanities. The series is a collaboration between Manchester University Press and the Society for the Social History of Medicine. 


\section{Payment and philanthropy in British healthcare, 1918-48}

George Campbell Gosling

Manchester University Press 


\section{Copyright (c) George Campbell Gosling 2017}

The right of George Campbell Gosling to be identified as the author of this work has been asserted by him in accordance with the Copyright, Designs and Patents Act 1988.

Published by Manchester University Press

Altrincham Street, Manchester M1 7JA

www.manchesteruniversitypress.co.uk

British Library Cataloguing-in-Publication Data

A catalogue record for this book is available from the British Library

Library of Congress Cataloging-in-Publication Data applied for

ISBN 9781526114327 hardback

ISBN 9781526114358 Open Access

First published 2017

An electronic version of this book is also available under a Creative Commons (CC-BY-NC-ND) licence. DOI: http://dx.doi.org/10.9760/MUPOA/9781526114358

The publisher has no responsibility for the persistence or accuracy of URLs for any external or third-party internet websites referred to in this book, and does not guarantee that any content on such websites is, or will remain, accurate or appropriate.

Typeset in 11 on 12 pt Arno Pro Regular by Toppan Best-set Premedia Limited 